JSIP: Jurnal Studi Ilmu Pemerintahan

Volume 2, No 2 Agustus 2021

ISSN: $2722-7405$

\title{
ANALISIS ANGGARAN PENDAPATAN BELANJA NEGARA(APBN) TERHADAP PENDANAAN KEBIJAKAN PENDIDIKAN
}

\begin{tabular}{|c|c|}
\hline \multicolumn{2}{|c|}{$\begin{array}{l}\text { Program Studi Ilmu Pemerintahan Universitas Muhammadiyah Malang } \\
\text { shalmanalfarizy12@gmail.com }\end{array}$} \\
\hline Article Info & \\
\hline $\begin{array}{l}\text { Keyword: } \\
\text { Budget }^{1}, \\
\text { Public Policy }^{2} \text {, } \\
\text { Education }^{3}\end{array}$ & $\begin{array}{l}\text { Abstract: The State Revenue and Expenditure Budget or APBN is the annual } \\
\text { financial plan of the state government approved by the House of } \\
\text { Representatives. The purpose of the preparation of the APBN is as a guideline for } \\
\text { state expenditures and revenues so that there is a dynamic balance in carrying } \\
\text { out state activities to achieve increased production, increased employment } \\
\text { opportunities, high economic growth and ultimately aimed at achieving a just } \\
\text { and prosperous material and spiritual society based on Pancasila and the } 1945 \\
\text { Constitution. "Indonesia is still behind several Asian countries in terms of } \\
\text { education, even though } 20 \text { percent of the state budget has been spent on } \\
\text { education for the last ten years. This is still not satisfactory. It may even be a } \\
\text { disappointment because Indonesian education graduates do not reach the } \\
\text { desired level. Equitable access to education and inadequate facilities and } \\
\text { infrastructure, especially in Eastern Indonesia and the Disadvantaged, Frontier, } \\
\text { Outermost (3T) areas. This is one of the challenges that the government will fix. } \\
\text { The results of this research are (1) the process of formulating education funding } \\
\text { policies reflects the lack of political will commitment from the government and } \\
\text { the DPR. (2) Implementation of the education funding policy of } 20 \% \text { of the } \\
\text { APBN. (3) Results of the education funding policy analysis. This study aims to } \\
\text { determine how to formulate education funding policies, their implementation } \\
\text { and analyze them. The method used in this study is a policy analysis method } \\
\text { with a retrospective policy analysis model and the type of policy process } \\
\text { analysis. }\end{array}$ \\
\hline
\end{tabular}

Kata Kunci:

Anggaran ${ }^{1}$,

Kebijakan',

Pendidikan ${ }^{3}$.
Abstrak: Anggaran pendapatan belanja negara atau APBN adalah rencana keuangan tahunan pemerintahan negara yang disetujui oleh Dewan Perwakilan Rakyat. Tujuan penyusunan APBN adalah sebagai pedoman pengeluaran dan penerimaan negara agar terjadi keseimbangan yang dinamis dalam rangk melaksanakan kegiatan-kegiatan kenegaraan demi tercapainya peningkatan produksi, peningkatan kesempatan kerja, pertumbuhan ekonomi yang cukup tinggi serta pada akhirnya ditujukan untuk tercapainya masyarakat adil dan makmur material maupun spiritual berdasarkan Pancasila dan UUD 1945. "Indonesia masih berada di belakang beberapa negara Asia dari segi pendidikan, padahal telah dikeluarkannya anggaran 20 persen dari APBN untuk edukasi selama 10 tahun terakhir. Ini masih belum memuaskan. Bahkan mungkin menjadi kekecewaan karena lulusan pendidikan Indonesia tidak mencapai level yang diinginkan. Pemerataan akses Pendidikan serta sarana dan prasarana yang belum memadai terutama di Indonesia Timur dan daerah Tertinggal, Terdepan, Terluar (3T) termasuk memprihatinkan. Ini menjadi salah satu tantangan yang akan diperbaiki pemerintah. Hasil dan penelitian ini adalah (1) proses perumusan kebijakan pandanaan pendidikan mencerminkan kurangnya komitmen political will dari pemerintah dan DPR. (2) Implementasi kebijakan pendanaan Pendidikan 20\% dari APBN. (3) Hasil analisis kebijakan pendanaan Pendidikan. Penelitian ini bertujuan untuk mengetahui bagaimana proses perumusan kebijakan pendanaan Pendidikan, implementasinya serta bagaimana analisisnya. Metode yang digunakan dalam penelitian ini adalah metode analisis 


\section{PENGANTAR}

Salah satu tujuan didirikannya negara Indonesia yang merdeka adalah untuk mencerdaskan bangsa (sebagaimana yang tercantum dalam pembukaanUUD 1945). Pasal 31 ayat 1 UUD 1945 juga menyebutkan, "Setiap warga negara berhak mendapatkan Pendidikan." Pasal ini kemudian dijabarkan lagi dalam UU No 20 tahun 2003 pasal 5 ayat2, "setiap warga negara mempunyai hak yang sama untuk memperoleh pendidikan yang bermutu." Srlain itu masih dalam Undang-undang yang sama, pasal 6 ayat 1 menyatakan, "Pemerintah dan pemerintah daerah wajib memberikan layanan dan kemudahan serta menjamin terselenggaranya Pendidikan bermutu bagi setiap warga negara tanpa diskriminasi."

Dari berbagai peraturan perundang-undangan di atas sangat jelas sekali seberapa besar tanggung jawab pemerintah terhadap mutu pendidikan bagi semua warga negara. Dalam menjalankan tuntutan tersebut negara berkewajiban menyusun kebijakan yang menjamin pendidikan yang bermutu dan tanpa diskriminas. Amandemen pasal 31 undang-undang 1945 merupakan kebijakan pendidikan yang kemudian muncul setelah berkali-kali terjadi kompromi politik.

Amandemen pasal ini dilakukan dengan tujuan untuk mempertegas komitmen pemerintah dan DPR pada pendidikan. Setelah mengalami beberapa kali amandemen pasal 31 telah memberikan jaminan kepada setiap warga negara untuk mendapatkan pendidikan yang bermutu. Hal tersebut dapat dilihat dalam pasal 31 ayat 4 yang menegaskan bahwa negara menerapkan amanat untuk memprioritaskan dana pendidikan sekurang-kurangnya $20 \%$ dari anggaran pendapatan dan belanja negara atau APBN dan anggaran pendapatan dan belanja daerah atau APBD.

Pendidikan yang didanai secara murah ini menyebabkan mutu penyelenggaraan dan layanan rendah. Padahal bila kita bercermin pada negara maju Mereka cenderung membelanjakan dana yang cukup besar untuk pendidikan mereka. Tingginya alokasi pendidikan di negara-negara maju tersebut terjadi karena meningkatnya political will pengambil keputusan terhadap pentingnya pendidikan.

Berbeda dengan beberapa negara-negara maju tersebut, di Indonesia justru masih stagnan bahkan berkesan mengalami kemunduran dalam mengalokasikan anggaran pendidikan. Hal tersebut karena alokasi pendanaan untuk pendidikan masih belum menjadi prioritas. Untuk itu pengkajian lebih lanjut tentang pendanaan pendidikan sebagaimana yang telah diatur dalam konstitusi merupakan suatu keharusan untuk merealisasikan konsep pendidikan yang bermutu bagi seluruh warga negara Indonesia.

\section{METODE PENELITIAN}

Metodologi yang digunakan adalah metode analisis kebijakan. Metodologi analisis kebijakan adalah proses pengkajian yang dirancang untuk menemukan solusi permasalahan secara praktis. Model analisis kebijakan yang digunakan yaitu analisis kebijakan retrospektif dengan jenisnya analisis proses kebijakan.

Model analisis kebijakan retrospektif yaitu usaha memproduksi dan mentransformasi informasi sesudah kebijakan dilaksanakan. Jenis analisis proses kebijakan yaitu terkait dengan proses perumusan, rumusannya, implementasinya, kinerja yang dicapai dan lingkungan di mana kebijakan tersebut berada. Dalam penelitian ini analisis proses kebijakan dibatasi pada proses perumusan dan implementasinya.

\section{HASIL DAN DISKUSI}

Pendidikan di Indonesia memang belum dianggap penting dalam memajukan bangsa, sehingga kebijakan tentang pendanaan pendidikan memang tidak pernah menjadi prioritas bagi pemerintah Indonesia dari dulu. mengapa hal ini terjadi dapat kita analisis dari segi perumusan kebijakan dan implementasi

\section{Perumusan Kebijakan}

Pasal 31 ayat 4 undang-undang Dasar 1945 menegaskan bahwa negara berdasarkan amanat untuk memprioritaskan dana pendidikan sekurang-kurangnya $20 \%$ dari anggaran 
pendapatan dan belanja negara atau APBN dan anggaran pendapatan dan belanja daerah atau APBD. Amanat undang-undang Dasar 1945 amandemen 4 tahun 2002, tersebut juga diatur dalam undang-undang nomor 20 tahun 2003 tentang sistem pendidikan nasional, yang berbunyi : dana pendidikan dialokasikan minimal 20\% dari anggaran pendapatan dan belanja negara atau APBN pada sektor pendidikan dan minimal 20\% dari anggaran pendapatan dan belanja daerah atau APBD.

Pasal ini merupakan penegasan komitmen DPR dan pemerintah untuk menjamin pendidikan yang bermutu di Indonesia. Namun munculnya pasal 49 ayat 1 undang-undang nomor 20 tahun 2003 tentang sisdiknas sebagai penjelasannya (pemenuhan anggaran pendidikan dapat dilakukan secara bertahap). Mengindikasikan hal lain. penjelasan pasal 49 ayat 1 ini bukannya memperjelas namun justru mereproduksi amanat undang-undang Dasar 1945. Pasal 31 undang-undang Dasar 1945 dimuat kata memprioritaskan namun dalam penjelasannya malah dimuat kata bertahap, di sini jelas terjadi kejanggalan antara pasal dan penjelasannya. Pasal 49 ayat 1 memunculkan norma hukum baru yang sama sekali berbeda dengan norma hukum pasal yangyang dijelaskan. Meskipun keduanya tidak bertentangan namun pasal 49 ayat 1 dalam melunturkan daya paksa pasal 31 undang-undang Dasar 1945. Ketentuan-ketentuan pada undang-undang Dasar 1945 adalah guru dari suatu negara itu sendiri, dimana ground nama tersebut merupakan cerminan dari kesepakatan tertinggi seluruh rakyat Indonesia. Oleh karena itu mau tidak mau Suka tidak suka pemerintah harus melaksanakan amanat konstitusi secara mutlak sebab hal tersebut sama artinya dengan menjalankan titah rakyat sepenuhnya.

Anggaran pendidikan yang dimaksud disini adalah apa yang dikenal sebagai anggaran pembangunan. Kemampuan fiskal bisa dilihat dari struktur pengeluaran APBN misalkan APBN 2004. Untuk tahun 2004 sekitar 15\% dari APBN akan digunakan untuk keperluan belanja pegawai, 19\% untuk membayar cicilan bunga hutang dan 31\% untuk transfer ke daerah. Itu merupakan jenis-jenis pengeluaran yang tak terhindarkan, baik karena terlanjur maupun karena ketentuan perundang-undangan. Pos tak terhindarkan itu total memakan sekitar $65 \%$ dari APBN. Perlu ditambahkan bahwa pada tahun 2004 ada beban subsidi sekitar 23 triliun atau 6\% dari anggaran (sebagian besar untuk subsidi BBM). Secara politis subsidi ini juga tak terelakkan mengingat resistensi yang demikian besar terhadap ide pencabutan subsidi pemerintah. Sedangkan anggaran untuk sektor lain juga penting mengingat eratnya kaitan sektor tersebut dengan kualitas SDM, misalnya sektor kesehatan.

Jauhnya persentase anggaran pendidikan yang disetujui panitia anggaran DPR dengan persentase yang diwajibkan konstitusi dinilai banyak pihak sebagai bentuk rendahnya komitmen Pemerintah terhadap dunia pendidikan. Padahal bila kita pahami bersama kemajuan pendidikan nasional memerlukan biaya yang tidak sedikit. Bukan hanya untuk peningkatan kualitas sarana pembelajaran seperti media pembelajaran laboratorium ruang keterampilan perlengkapan belajar dan berbagai peranti keras lainnya, akan tetapi juga pada aspek peningkatan kesejahteraan guru yang cukup penting dan tidak bisa diabaikan. Semua itu akan bersinergi dan berbanding lurus dengan peningkatan kualitas pendidikan. Namun tuntutan secara yuridis formal tersebut terbentuk oleh berbagai dalih yang dibuat oleh pemerintah dan DPR (eksekutif dan legislatif) tentang anggaran pendidikan. Maka tidak salah memang ketika dinyatakan bahwa kebijakan identik dengan kebijakan pemerintah yaitu kebijakan yang hanya menanamkan nilainilai kelompok elit yang memerintah saja. Kalau memang ada komitmen dan political will dari pemerintah dan DPR dengan otoritas yang dimilikinya, seharusnya dapat memenuhi anggaran pendidikan sebesar $20 \%$ diluar gaji guru dan biaya kedinasan.

\section{Implementasi Pendanaan Pendidikan}

Implementasi kebijakan pendanaan pendidikan sekarang sudah dapat kita lihat bersama. Dalam undang-undang nomor 20 tahun 2003 mengenai sistem pendidikan nasional pengertian pendidik sangat luas. pasal 1 angka 6 menyebutkan bahwa pendidik adalah tenaga kependidikan yang berkualifikasi sebagai guru dosen, konselor, Pamong belajar, widyaiswara, tutor, instruktur, fasilitator dan sebutan lain yang sesuai dengan kekhususannya serta berpartisipasi dalam penyelenggaraan pendidikan.

Sesuai dengan amanat pembangunan pemerintah yang dituangkan dalam buku RKP 2013 yang menjelaskan bahwa tujuan dan visi pengembangan pendidikan yaitu menuntaskan program 
wajib belajar pendidikan dasar 9 tahun bagi sekitar 45 juta siswa SD dan SMP, meningkatkan kualitas pendidikan, serta jaminan atas keberlangsungan program pendidikan bagi generasi. maka dalam rincian RAPBN 2013 pemerintah akan mengalokasikan biaya tersebut ke dalam masing-masing sasaran pembangunan sebagai berikut:

1. melanjutkan program bantuan operasi sekolah untuk membebaskan biaya pendidikan dalam rangka penuntasan wajar 9 tahun;

2. menyediakan bantuan bagi siswa yang kurang mampu agar bisa melanjutkan pendidikan dan memberikan Beasiswa bagi siswa berprestasi;

3. menyediakan tunjangan yang lebih banyak bagi profesi guru dengan tujuan peningkatan kualitas Pendidikan.

Meningkatnya belanja publik di sektor pendidikan telah sangat membantu memperluas akses, dan meningkatkan angka partisipasi sekolah selama satu dekade terakhir, terutama di kalangan siswa miskin. Namun peningkatan angka partisipasi ini lebih terlihat di tingkat wajib belajar 9 tahun, sekolah dasar dan level pendidikan menengah pertama.

\section{Analisis Kebijakan}

Anita Liye dalam artikelnya yang berjudul "pendidikan dalam dinamika globalisasi" mengemukakan bahwa untuk memajukan dunia pendidikan dibutuhkan suatu komitmen dan kemauan yang kuat dari tampuk kepemimpinan nasional. Kalau memang ada komitmen dan political will dari pemerintah dan DPR dengan otoritas yang dimilikinya, seharusnya dapat memenuhi anggaran pendidikan sebesar $20 \%$ diluar gaji guru dan biaya kedinasan. Tidak adanya kemauan eksekutif dan legislatif untuk benar-benar menjalankan kewajiban konstitusional tersebut membuat Indonesia harus membayarnya dengan mutu pendidikan yang rendah. Padahal dalam pasal 31 ayat 4 undang-undang Dasar 1945, secara jelas dinyatakan bahwa pemerintah mempunyai suatu kewajiban konstitusi (constitutional obligation) untuk memprioritaskan anggaran pendidikan sekurang-kurangnya 20\% dari APBN dan APBD guna memenuhi kebutuhan penyelenggaraan Pendidikan Nasional. Implementasi pemenuhan anggaran $20 \%$ yang bercampur dengan gaji pendidikan dan biaya kedinasan merupakan sebuah penghianatan terhadap kewajiban konstitusional pemerintah. Implementasi seperti ini membuat pendanaan pendidikan menjadi tidak efektif. Untuk itu pemerintah seharusnya meninjau ulang kebijakan alokasi pendanaan pendidikan dan benar-benar mengalokasikan $20 \%$ dana dari APBN dan APBD untuk pendidikan di luar gaji guru dan biaya kedinasan.

Martin kurman mengarahkan bahwa kebijakan pendidikan merupakan bagian dari kebijakan negara. political will dan Power government memiliki pengaruh besar dalam setiap kebijakan pendidikan. Sikap pemerintah yang terus-menerus berupaya menyiasati pemenuhan alokasi anggaran 20\% untuk sektor pendidikan diluar gaji pendidik dan biaya kedinasan menunjukkan dua hal. Pertama tidak ada niat baik pemerintah untuk memenuhi amanat konstitusi. Kedua pemerintah tidak menempatkan pendidikan sebagai sektor prioritas dalam mendorong kemajuan bangsa.

\section{KESIMPULAN}

Anggaran adalah perencanaan yang rinci untuk masa depan yang dinyatakan secara kuantitatif dan lebih spesifik memperlihatkan Bagaimana sumber daya didapat dan digunakan pada periode tertentu dengan mengidentifikasi tujuan dan tindakan yang diperlakukan untuk mencapainya. APBN adalah rencana keuangan tahunan pemerintah negara yang disetujui oleh Dewan Perwakilan Rakyat. Anggaran pendidikan merupakan salah satu komponen penting bagi berjalannya pembangunan manusia di sebuah daerah. Dikarenakan adanya jaminan terhadap kualitas sumber daya manusia yang ada Serta adanya kemampuan untuk menjaga sumber daya manusia yang dimiliki. Dengan terjaminnya hal tersebut maka akan diharapkan akan meningkatkan indeks pembangunan manusia yang dimiliki dan nantinya berkontribusi pada pendidikan

\section{REFERENSI}

Ace Suryadi dan H.A.R. Tilaar. (1994). Analisis kebijakan pendidikan: suatu pengantar. Bandung: Rosdakarya 
H.A.R. Tilaar dan Riant Nugruho. (2008). Kebijaka pendidikan: pengantar untuk memahami kebijakan Pendidikan dan kebijakan Pendidikan sebagai kebijakan public.

Yogyakarta: Pustaka belajar.

William Dun. (2003). Pengantar Analisis Kebijakan Publik. Yogyakarta: Gadjah Mada University Press

UU No. 20 Tahun 2003 tentang Sistem Pendidikan Nasional PP No. 48 Tahun 2008 tentang Pendanaan Pendidikan Putusan MK Nomor 011/PUUIII/2005, tanggal 19 Oktober 2005 Putusan MK Nomor 24/PUUV/2007, tanggal 20 Februari 2008. 
